\title{
Influence of marine salts on the localization and accumulation of surfactant in the needles of Pinus halepensis Mill
}

\author{
B Richard 1 , P Grieu², PM Badot 3 , JP Garrec ${ }^{1}$ \\ ${ }^{1}$ Unité d'écophysiologie forestière, laboratoire de pollution atmosphérique, \\ centre de recherche de Nancy, Inra, 54280 Champenoux; \\ ${ }^{2}$ Laboratoire agronomie et environnement, Ensaia-Inra, BP 172, 54505 Vandceuvre; \\ 3 Institut des sciences et techniques de l'environnement, antenne Nord-Franche-Comté, \\ laboratoire sciences végétales, pôle universitaire, \\ 4, place Tharradin, BP 427, 25211 Montbéliard, France
}

(Received 16 October 1995; accepted 19 December 1995)

\begin{abstract}
Summary - To simulate the conditions of polluted sea sprays during storms, trees were exposed to a short pollution episode. Two-year-old pines (Pinus halepensis Mill) were dipped for a short time in a water or saline solution of $\left.{ }^{35} \mathrm{~S}\right]$ linear dodecyl benzene sulfonate. The surfactant was absorbed by plants to a greater extent in synthetic sea water than in distilled water. This greater absorption raised the level of pollution in plants growing close to the seashore. The surfactant accumulated mainly in the epicuticular wax of the needles, and this accumulation was two times higher when the pollutant was supplied in a saline solution than in distilled water. Rapid alterations to the epicuticular wax structure were confirmed by scanning electron microscopy.
\end{abstract}

\section{Pinus halepensis / needle / cuticular wax / surfactant / sea water}

Résumé - Influence des sels marins sur la localisation et l'accumulation des tensioactifs dans les aiguilles de Pinus halepensis Mill. Afin de simuler des conditions de pollution par les embruns marins pollués lors de tempêtes, les arbres sont exposés à de courts épisodes de pollution. Des pins agés de 2 ans (Pinus halepensis Mill) sont trempés dans une solution saline de [ ${ }^{35}$ S] dodécyle benzène sulfonate linéaire. Le tensioactif en solution dans l'eau de mer est davantage retenu par les plants qu'en solution dans l'eau distillée. Cette plus grande rétention élève le niveau de pollution des plants près des côtes du bord de mer. Le tensioactif s'accumule principalement dans les cires épicuticulaires des aiguilles et l'accumulation est deux fois plus importante quand le polluant est appliqué par le biais d'une solution saline plutôt que dans de l'eau distillée. Des altérations rapides de la structure des cires épicuticulaires sont confirmées par microscopie électronique à balayage.

Pinus halepensis / aiguille / cire cuticulaire / tensioactif / eau de mer

Abbreviations: LABS linear dodecyl benzene sulfonate; SEM: scanning electron microscopy; PFD: photosynthetic flux density; Aww2min: accumulation coefficient. 


\section{INTRODUCTION}

For a long time, symptoms of decline have been described on vegetation growing near the Mediterranean coasts in the Bouches du Rhône, France (Deveze and Sigoillot, 1978; Sigoillot, 1982; Garrec and Sigoillot, 1992; Crouzet and Resch, 1993), and in Italy (Gellini et al, 1985; Guidi et al, 1988; Clauser et al, 1989; Loglio et al, 1989; Bussotti et al, 1995). Similar observations were made in Australia on the Sydney coastline (Pitman et al, 1977; Grieve and Pitman, 1978; Dowden and Lambert, 1979; Moodie et al, 1986).

The feature common to this decline, which affects both herbaceous and woody plants, is the reduction in foliage volume due to the early loss of leaves. Typically, the leaf tips turn brown and a premature leaf abscission occurs on the seaward side of the trees. Serious damage may lead to the death of the woody plant. It has been suggested that this tree decline was indirectly caused by domestic and commercial detergents (Sigoillot, 1982).

Synthetic surfactants are compounds in widespread use and their total production rate reaches $7 \times 10^{6} \mathrm{t}$ per year (Tools et al, 1994). About half of this amount is devoted to domestic cleaning, while industrial use accounts for the second half (Thoumelin, 1990). Large amounts of surfactants are released into waste water and contribute to the pollution of the environment despite waste treatment facilities (Kloster et al, 1993; Tools et al, 1994). About two-thirds of the total surfactants consist of anionic compounds, that is, soap and linear alkyl benzene sulfonate surfactants. Linear dodecyl benzene sulfonate (LABS), with an alkyl chain of 12 carbons, is predominantly found in untreated sewage outlets flowing into natural waters and sea. LABS can often be detected in droplets produced by rivers or in sea aerosols (Giovannelli et al, 1988). In relation to airborne formation, the LABS concentration may be from ten to 100 times more concentrated in sea spray than in sea water (Sigoillot, 1982). The role of salt spray as an environmental factor in coastal ecology and its effects on plants has been recognized by many authors (Wells and Shunk, 1938; Oosting, 1945; Pyykkö, 1977; McWilliams and Sealy, 1987).

A great deal of information has been obtained concerning nonionic surfactants commonly employed in the penetration of foliar-applied agrochemicals (Berndt, 1987; Coret et al, 1993). The surfactant phytotoxicity has been estimated (Coupland et al, 1989) and injuries have been described in selected Pinus spp after application of de-icing salt sprays (Barrick et al, 1979). In contrast, very little is presently known about the mechanisms that could occur to explain an interaction of anionic surfactant and salt spray causing severe damage to plants. Grieve and Pitman (1978) observed an increased level of chloride in plant tissues and severe damage to leaves when surfactants and salt were sprayed in combination. In this paper, we report the influence of marine salt on the leaf uptake of LABS in Pinus halepensis Mill. To mimic the conditions found during storms, trees were exposed to a short pollution episode. $P$ halepensis Mill is a species of tree which has a great importance in the landscape of the south of France. Resistant to drought and a halophile species, it has a remarkable ability to colonize the space taken free by more sensitive plants, and is often grown in recreational areas.

\section{MATERIALS AND METHODS}

\section{Plant material}

Seedlings of $P$ halepensis Mill of Mediterranean origin (Saint-Étienne-du-Grès) were grown for 6 months in the nursery of the Direction départementale de l'agriculture (Les Milles, Bouchesdu-Rhône, France). They were then transferred 
to $1.5 \mathrm{~L}$ pots and kept during 18 months in controlled conditions: $16 \mathrm{~h}$ photoperiod, $24^{\circ} / 16^{\circ} \mathrm{C}$ (day/night) temperature and $50 \%$ constant relative humidity. Light irradiance was controlled using a Licor quantum sensor, and the photosynthetic flux density (PFD) at the top of the shoots was about $380 \mu \mathrm{mol} \mathrm{m} \mathrm{m}^{-2} \mathrm{~s}^{-1}$. From October to May, plants were supplied with additional mercury vapor lamps. Experiments were run on 30 plants.

\section{Plant labeling}

After the dark period, 20 pines were exposed to a radiolabeled anionic surfactant: $\left.{ }^{35} \mathrm{~S}\right]$ LABS obtained from Dr Sigoillot (University of SaintJérôme, Marseille, France). LABS was labeled with $\left[{ }^{35} \mathrm{~S}\right]$ in the sulfophenyl ring and had a specific radioactivity of $8712 \mu \mathrm{Ci} / \mathrm{mol}$. [ ${ }^{35} \mathrm{~S}$ ] LABS was dissolved in both distilled and synthetic sea water (Lyman and Fleming formula; Sigoillot, 1982) at a concentration of $1.7 \times 10^{-4} \mathrm{~mol} \mathrm{~kg}^{-1}$ $\mathrm{H}_{2} \mathrm{O}$ at $22{ }^{\circ} \mathrm{C}$. Three batches of ten pines were immersed during $2 \mathrm{~min}$ in distilled water alone (batch 1), in LABS-distilled water (batch 2) and in LABS-sea water (batch 3). These solutions were applied on ten plants each to reproduce the effects of severe storms on the seashore, or the accumulation of droplets produced by a polluted river and to serve as controls (batch 1). Only aerial parts of plants were immersed in a large volume of [ ${ }^{35} \mathrm{~S}$ ] LABS solution (in a container measuring $50 \times 50 \times 8 \mathrm{~cm}$ ) in which was placed $1 \mathrm{~L}$ of solution to allow a homogeneous labeling during a short time exposure. The root system was isolated from the LABS solution by a plastic bag which was closed at the collar. Controls were run on ten plants. Trees were removed from the respective solution and gently shaken to eliminate liquid droplets. Radiolabeled and control trees were kept in a greenhouse for $48 \mathrm{~h}$ under the following day/night conditions: $16 \mathrm{~h} / 8 \mathrm{~h}$ photoperiod, $22 \% 16{ }^{\circ} \mathrm{C}$ temperature and $70 \%$ constant relative humidity. Before analysis, trees were washed twice in distilled water for $1 \mathrm{~min}$ while shaking to simulate rainfall. The two washing solutions were collected and constituted the fraction of LABS that was not retained by the plants.

Trees were cut back at the soil surface. The aerial part was divided as follows: 1 , epicuticular wax from needles; 2 , dewaxed needles; 3 , remaining plant material: branches without needles and tree stem. Needles of each plant were sampled by submerging the branches into liquid nitrogen. Broken needles were separated and discarded. The integrity was visually verified to keep only uninjured needles and to avoid the radiolabeled solution infiltrating through needles. Epicuticular waxes were extracted twice from distilled water washed needles by shaking for $30 \mathrm{~s}$ in $50 \mathrm{~mL}$ of chloroform for each extraction and kept at room temperature. The extract was reduced to dryness under vacuum in a rotavapor (Büchi RE 111, Flawil, Sweden) and freeze-dried (Bioblock, FTS System Inc, IIIkirch, France). The freeze-dried wax was weighed and wet mineralized by oxidative reagents $\mathrm{HNO}_{3} / \mathrm{H}_{2} \mathrm{O}_{2}$ with $\mathrm{H}_{2} \mathrm{SO}_{4}$ as support and stabilizing (Hoenig, 1981). The branches and dewaxed needles were dried separately at $105^{\circ} \mathrm{C}$ for $72 \mathrm{~h}$ and stored for $48 \mathrm{~h}$ at room temperature in a dessicator. Oven-dried dewaxed needles and branches from each tree were reduced to very small pieces $(<2 \mathrm{~mm})$ and mineralized as previously described. Radioactivity was measured in each fraction by using a liquid scintillation cocktail obtained from Packard (Ultima Gold Packard, 6013329) and a Packard Tricarb 460 CD spectrometer (Meriden, USA).

In order to determine the sorption of LABS into the different sampled fractions of the plant (epicuticular wax, dewaxed needles or branches without needles and stem), the percentage of the total activity (\%TA) incorporated into the different sampled fractions of the plant was calculated as follows:

$$
\begin{gathered}
\% \text { TA of a } \\
\text { sampled fraction }=
\end{gathered}
$$

A coefficient of LABS accumulation in waxes, between epicuticular wax and water, was defined for LABS as the accumulation coefficient obtained for plants after dipping them for $2 \mathrm{~min}$ in a radiolabeled solution (LABS-distilled water or LABS-sea water). This coefficient was called Aww2min.

$$
\text { Aww2min }=\frac{\begin{array}{c}
\text { Concentration of }\left[{ }^{35}\right. \text { S] LABS } \\
\text { in epicuticular waxes fraction }
\end{array}}{\begin{array}{c}
\text { Concentration of } \left.{ }^{35} \mathrm{~S}\right] \text { LABS } \\
\text { in radiolabeled water solution }
\end{array}}
$$

\section{Scanning electron microscopy (SEM)}

Forty-eight hours after exposure to pollution, ten needles from each of the five replicates, from two 
batches of treated plants and from control plants, were cut into small segments and air-dried. They were fixed on small aluminum stubs with conductive glue (Leit C, Boiziau Distribution, Selles-surCher, France) and carbon-coated (metallizer balzer's CED/020, Boiziau Distribution, Sellessur-Cher, France). Adaxial surfaces were examined with a Stereoscan $90 \mathrm{~B}$ electron microscope (Cambridge Instruments, Cambridge, UK). Observations in the scanning mode were performed with a $15 \mathrm{kV}$ acceleration voltage.

\section{Statistics}

Results are given as means with $95 \%$ confidence intervals. The statistical treatment employed was the analysis of variance (ANOVA) by the GLM procedure (SAS Institute Inc, 1985). The test of equality of averages using StudentNewman-Keuls was also applied.

\section{RESULTS}

In order to consider only plants with no significant differences in terms of biomass, only five of each batch of $P$ halepensis Mill were selected (table I). Forty-eight hours after the pollution application, half of the radioactivity detected on the plant was found in the epicuticular waxes and nearly all the rest was in the washing solution (table I). The LABS proportion found in the washing solution of LABS-sea water plants was seven times greater than that of the LABS-distilled water plants (table I). This proportion corresponded to 1.4 and $0.2 \%$ of the original quantity of LABS supplied in the two polluted solutions, respectively.

To estimate the surfactant retention on the plant surface, the distribution of LABS sorbed after the distilled water wash is shown in table II. Interestingly, the average amount of LABS accumulated in the epicuticular wax was $10 \times 10^{-3} \mathrm{mg} \mathrm{mg}^{-1}$ of wax dry weight in plants treated by LABS-sea water, but was twice less in plants immersed in LABS-distilled water. Moreover, the accumulation coefficient (Aww2min) was 166 for the epicuticular waxes in the presence of sea water and 82 with distilled water. More than $95 \%$ of the incorporated radioactivity was detected in the epicuticular waxes whatever the polluted solution used (table II). In contrast, the incorporation of LABS in other sampled aerial fractions (ie, dewaxed needles and branches) was extremely low (about $10^{-6} \mathrm{mg} \mathrm{mg}^{-1} \mathrm{dry}$ weight) in both treatments (table II).

The nature of the polluted solution did not influence the relative distribution of LABS among the three sampled fractions (table II). No statistically significant difference in the percentage of specific activity was shown for the wax fraction, the dewaxed needles nor the remaining plant material. However, LABS was detected in the dewaxed needles of three plants treated by

Table I. Biomass of treated trees and the amount of LABS in the analyzed fractions of Pinus halepensis Mill trees expressed as the percent of the original quantity supplied in the external solution.

\begin{tabular}{lccc}
\hline & $\begin{array}{c}\text { Control-distilled } \\
\text { water treatment } \\
\text { (batch 1) }\end{array}$ & $\begin{array}{c}\text { LABS-sea water } \\
\text { treatment } \\
\text { (batch 2) }\end{array}$ & $\begin{array}{c}\text { LABS-distilled } \\
\text { water treatment } \\
\text { (batch 3) }\end{array}$ \\
\hline Aerial parts dry weight $(\mathrm{g})$ & $4.55 \pm 0.08$ & $4.77 \pm 0.62$ & $4.41 \pm 0.15$ \\
& & & \\
Amount of LABS as \% of total in solution & $\sim 0$ & $1.48^{\star} \pm 1.03$ & $0.18 \pm 0.10$ \\
Epicuticular waxes & -0 & $0.09 \pm 0.16$ & $\sim 0$ \\
Dewaxed needles & $\sim 0$ & $\sim 0$ & $\sim 0$ \\
Remaining plant material & -0 & $1.41^{\star} \pm 0.57$ & $0.17 \pm 0.06$ \\
Distilled water wash & & & \\
\hline
\end{tabular}

$n=5 ;{ }^{*} P<0.05 ;$ values are given as mean $\pm \mathrm{SD}$. 
Table II. [ ${ }^{35}$ S]LABS uptake, and percent of the specific activity incorporated (\%TA) in the different analyzed fractions of the plant after distilled water wash. Amount of [ $\left.{ }^{35} S\right]$ LABS was calculated from dry weight of each analyzed fraction.

\begin{tabular}{lcc}
\hline & $\begin{array}{c}\text { LABS-sea } \\
\text { water treatment }\end{array}$ & $\begin{array}{c}\text { LABS-distilled } \\
\text { water treatment }\end{array}$ \\
\hline${ }^{35}$ S $]$ LABS uptake $\mu \mathrm{g} \cdot \mathrm{mg}^{-1}$ dry weight & & \\
Epicuticular waxes & $9.96^{*} \pm 3.10$ & $4.90 \pm 1.10$ \\
Dewaxed needles & $0.007 \pm 0.001$ & $\sim 0$ \\
Remaining plant material & $0.006 \pm 0.001$ & $\sim 0$ \\
& & \\
\% of specific activity (\%TA) & $89.70 \pm 6.02$ & $96.90 \pm 2.34$ \\
Epicuticular waxes & $9.90 \pm 5.95$ & $\sim 0$ \\
Dewaxed needles & $0.37 \pm 0.23$ & $3.10 \pm 0.02$ \\
Remaining plant material & & \\
\hline
\end{tabular}

$n=5$; ${ }^{*} P<0.05$; values are given as mean \pm SD.

LABS-sea water. The two remaining plants were not affected. No penetration of LABS was observed under the cuticular wax layer when LABS was supplied in LABS-distilled water.

In the conditions of our experiment, no symptoms of decline were visually observed. However, after application of LABS in distilled or sea water, SEM observations of needles showed a severe degradation of the epicuticular wax morphology (fig 1B, C). Needle surface of water control plants, which were not treated by LABS, were entirely covered with a web of crystalloid microtubules that also lined the stomatal chamber (fig 1A). Microtubules observed in the epicuticular wax disappeared after treatment with LABS-sea water. An amorphous layer of wax replaced the normal microtubular network (fig 1C). When plants were treated with LABS-distilled water, similar damage was observed, except for the stomatal line and around the stomatal pore, where waxes conserved a crystalloid shape (fig 1B).

\section{DISCUSSION}

The surface of higher plants represents the largest interface between the biosphere and the atmosphere. It is constituted of a thin extracellular membrane called the plant cuticle. Its matrix consists of the amorphous polymer cutin formed by crosslinked hydroxyalkanoic acids and supports intra- and epicuticular waxes. The epicuticular waxes play a central role during the foliar uptake but also the trichomes and the large differences in the rates of foliar uptake resulting from the varying specific leaf surface areas (Riederer and Schreiber, 1995). Needle waxes of $P$ halepensis Mill are covered by epicuticular tubules and analysis of the chemical composition of epicuticular waxes revealed a major compound: nonacosan-10-ol (Riederer et al, 1995).

In this paper, we demonstrate that high amounts of dodecyl benzene sulfonate could accumulate in the leaf cuticle of $P$ halepensis Mill after a 2 min immersion of the foliage in a saline solution of LABS simulating a storm. According to Schreiber and Schönherr (1993), the plant leaves in relation to their cuticular waxes will act as very effective scavengers towards organic chemicals occurring in the environment. Schreiber and Schönherr (1992) defined the term 'foliar uptake' as the amounts of active ingredients and adjuvants that are sorbed or bound to any of the various leaf compartments including epicuticular 


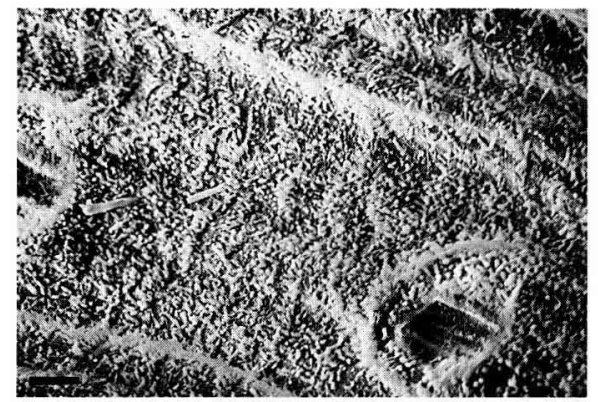

A

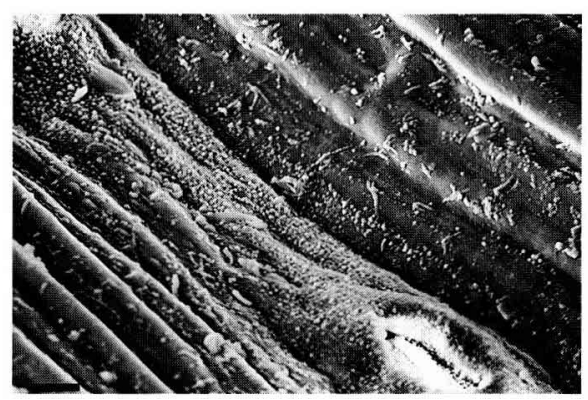

B

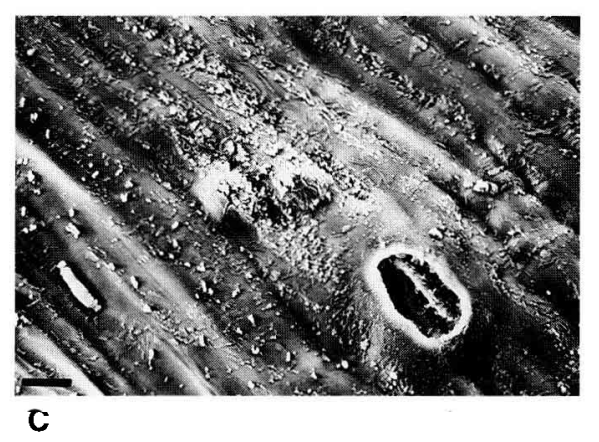

Fig 1. Wax structure on $P$ halepensis Mill needles and the subsidiary cells of the stomata (black bar scale $=10 \mathrm{~m}$ ). A. Finely distributed tubular wax crystalloids cover the stomata and the cuticle surface of water control plants. B. Alteration of cuticular waxes after treatment by LABS-distilled water. Epicuticular wax tubes disappeared except on the stomatal line. C. Alteration of cuticular waxes after treatment by LABSsea water. An amorphous layer had replaced the microtubular network. waxes and cuticle. As Bukovac and Petracek (1993), they suggested that the transport of the solutes through the cuticle consists of a series of consecutive steps: i) sorption to the surface of leaves, ii) diffusion into surface waxes, iii) diffusion across the cutin encrusted with the embedded waxes and finally iv) diffusion across cell walls and accumulation in cytoplasm of epidermal cells.

The fraction of LABS found in the distilled water wash may be the fraction of LABS associated with the leaf surface. Sorption of organic materials onto the leaf surface is poorly known; however, the amount of LABS found at this level may be related to a 'crystalline' or free form that was not retained by the epicuticular wax. The fraction of LABS found in the chloroform extract results from the sorption and diffusion of molecules into epicuticular waxes and a part of the LABS probably diffuses across the cutin encrusted with embedded waxes. No significant amount of LABS was detected in dewaxed needles (cutin, intracuticular wax and mesophillic tissues) and the remaining plant material. It may be related to a large sorption on the epicuticular cuticular waxes, or the lack of LABS source/sink relationships (metabolization, translocation away from the epidermis) which allow the accumulation of chemicals in the cuticle as suggested by Schönherr and Riederer (1988). The relative amounts of solute contained in cuticles and waxes would also depend on the time of exposure. Uptake of chemicals into conifer needles proceeds in two distinct phases (Screiber and Schönherr, 1992). The first rapid phase was attributed to sorption of the chemicals to the needle surfaces, the second represented penetration across cuticles and accumulation in the needle interior. Interestingly, after a brief exposition to the LABS-sea water solution, a low quantity of LABS was sometimes detected in dewaxed needles. This presence of LABS probably indicates a sorption of LABS in 
embedded intracuticular waxes and/or cutin, which are not extracted by chloroform.

The difference in $\mathrm{pH}$ values between LABS in sea water $(\mathrm{pH}=7.3)$ and LABS in distilled water $(\mathrm{pH}=4.6)$ could not explain a difference in the foliar uptake of the surfactant because the dissociation constant of the dodecyl benzene sulfonic acid would be very similar to the pKa saline of the benzene sulfonic acid $\mathrm{pKa}=0.7$. Moreover, the cuticle carries a net negative charge at these two $\mathrm{pH}$ values (Schönherr and Huber, 1977; Chamel et al, 1992). Consequently, in both distilled and sea water, LABS would be at least $99 \%$ in its anionic form and the cuticle negatively charged would be in the same state of capacity exchange and permeability for ionic solution. Previous studies have reported that ionized molecules such as organic acids are only sorbed in their non-ionized form (Schönherr and Riederer, 1989). Consequently, in this study, the accumulation of ionized LABS form in cutin should not occur.

Occurrence of $L A B S$ in dewaxed needles would perhaps result from a penetration of LABS solution through the stomata. The fundamental requirement for stomatal infiltration is a low surface tension $(<25-30$ $\mathrm{mNm}^{-1}$ ) which can be provided only by some surfactant (Schönherr and Bukovac, 1972; Steven et al, 1991). At the LABS concentration we used in this experiment, the surface tension of LABS in distilled water was $45 \mathrm{~m} \mathrm{Nm}^{-1}$, while in the presence of sea salt, the value decreased to $29 \mathrm{mNm}^{-1}$ (Grieve and Pitman, 1978). In sea salt solution, LABS reached the surface tension value to which spontaneous stomatal infiltration was observed. In Araucaria heterophylla, Grieve and Pitman (1978) showed that, when the surface tension was low, microtubular waxes would act as a wick, aiding rather than preventing entry of solution to the stomatal pore. Interestingly, we observed microtubules on the wall of the stomatal antechambers of $P$ halepensis
Mill. These microtubules could facilitate the entry of LABS into the stomata of $P$ halepensis Mill when the surface tension is low.

The greater value of accumulation coefficient (Aww2min) of LABS in the cuticular waxes in the presence of sea water suggests an influence of inorganic salts on LABS sorption. Synthetic sea water, composed of nine major salts (Sigoillot, 1982), was used to simulate airborne water in controlled conditions. In order to standardize the experimental conditions, no additional component generally found in natural sea water (ie, petroleum hydrocarbon or heavy metal salt) were supplied. Inorganic salts increase the ionic strength of LABS solution. Consequently, the addition of such electrolyte facilitates both adsorption and micellization at the liquid/air interface: LABS adsorption is higher by the lesser repulsion between oriented ionic heads of LABS surfactant and the critical micelle concentration is decreased by diminishing the driving force leading to micelle formation (Rosen, 1977). At the LABS concentration we used in this experiment, micelles were formed in the salt solution, while in distilled water LABS was mainly present in its monomeric form. An important physical property of such micelles is the ability to enclose apolar solutes in a polar solution, ie, the solubilization of wax in mixed surfactant micelles (Stock and Holloway, 1993). The amount of epicuticular waxes extracted from needles treated with LABS in sea water was not significantly different from that found with LABS in distilled water (data not shown). Consequently, after short exposure to LABS pollution, the micelles of LABS should not render soluble the epicuticular waxes of $P$ halepensis Mill.

When LABS came into contact with the needle surface of $P$ halepensis Mill, it did not cause a loss of waxes, but serious changes in the epicuticular wax fine structure were noticed with more dramatic effects when LABS was in saline solution. Similar observations were made on 
needles collected from damaged $P$ halepensis Mill trees on the Mediterranean coast in France (Badot et al, submitted), as well as in Italy, on damaged $P$ pinea trees on the Tyrrhenian coast (Bussotti et al, 1995) and Quercus ilex (Moricca et al, 1993). It has been shown that the highly ordered and crystalline waxes limit the sorption of solutes across isolated plant cuticles (Bukovac and Petracek, 1993). However, it cannot be concluded that cuticular permeability increases if epicuticular waxes are eroded (Schreiber, 1994). The exact mechanism of surfactant action at the cuticular level is poorly known. Chamel et al (1992) suggested that ethoxylated nonylphenol surfactants have some effects on swelling and hydration of the isolated cuticular membrane, which contribute to the increase of the diffusivity. Recently, Jetter and Riederer (1994) interpreted the alterations of the fine structure of epicuticular tubules on Picea pungens by air pollutants as a spontaneous transition from the tubular to the planar modification of (S)-nonacosan-10-ol crystals. The tubular crystals would be thermodynamically metastable and the planar crystals more stable. After short exposure to LABS, our results would suggest that epicuticular waxes localized on the stomatal line and around the stomatal pore would stay more in the tubular crystal shape than other epicuticular wax localized on the rest of the cuticle. Experiments with trichloroacetate on Pinus radiata have shown that these two sorts of epicuticular waxes with different localizations have not the same biosynthesis pathway (Franich and Wells, 1980). Previously, in identical conditions of short time exposure and plant material as described in this paper, $P$ halepensis Mill have been treated by pure sea water (Richard, unpublished data). SEM observations of needle surface of these treated plants showed an alteration of the crystalloid aspect of the epicuticular waxes. Microtubules appeared to be only identically broken on all the surface of the cuticle as well as near the sto- matal pore. In contrast, on all cuticular surface of needles, LABS-sea water would induce a fast disappearance of tubular crystal of epicuticular waxes. This would suggest a more rapid disappearance of tubular crystals of $P$ halepensis Mill epicuticular waxes after LABS-sea water treatment, than after LABS-distilled water or sea water alone, especially for epicuticular waxes lining the stomata.

After short LABS exposure, our results provide evidence that foliar uptake of LABS was more effective in sea water than in distilled water. This suggests that LABS pollution in combination with sea water is more easily taken-up by the $P$ halepensis Mill needles. In fact, similar conditions of the synergistic action of LABS and sea salts occur in sea spray near the polluted Mediterranean seashore. This polluted sea spray is conveyed onto the foliage by wind during storms and damage the coastal vegetation. LABS accumulation in the needles of $P$ halepensis Mill needs to be confirmed on pines growing in natural conditions, where LABS penetration may be facilitated by the occurrence of other pollutant substances, or across microfissures of the cuticle, caused by the insects, the action of phytopathogen organisms or the impact of sand and dust.

\section{ACKNOWLEDGMENTS}

Thanks to Dr V Stepien (University of Uppsala, Sweden), Pr P Faller (University of Metz, France) and Dr J Neil Cape (Institute of Terrestrial Ecology of Edinburgh, UK) for helpful discussions during the course of this work. Thanks to PC Vong for advice on using the spectrometer and $G$ Nourrisson on using the scanning electron microscope. The language of the manuscript was checked by $M$ Dixon. We wish to express our gratitude to the French-German Eureka-Eurosilva Research Programme for financial support.

\section{REFERENCES}

Astorga T, Lopez D, Carazo N, Savé R (1993) Effecto del viento marino en la vegetacion urbana del nuevo 
litoral Barcelonés. Actas del // Congresso Iberico SECH, Spain, 539-545

Barrick WE, Flore JA, Davidson H (1979) De-icing salt spray injury in selected Pinus spp. J Am Soc Hortic Sci 104, 617-622

Berndt GF (1987) Efficiency of foliar sprays as influenced by the inclusion of surfactants. Res Dev Agric 3, 129-139

Bukovac MJ, Petracek PD (1993) Characterizing pesticide and surfactant penetration with isolated plant cuticles. Pestic Sci 37, 179-194

Bussotti F, Grossoni P, Pantani F (1995) The role of marine salt and surfactants in the decline of Tyrrhenian coastal vegetation in Italy. Ann Sci For 52, 251261

Chamel A, Gambonnet B, Coret J (1992) Effects of two ethoxylated nonylphenols on sorption and penetration of $\left[{ }^{14} \mathrm{C}\right]$ isoproturon through isolated plant cuticles. Plant Physiol Biochem 30, 713-721

Clauser F, Gellini R, Bussotti F, Cenni E, Bottacci A (1989) New types of damage to forest trees typical of the Mediterranean region. Eur J For Path 19, 7883

Coret J, Gambonet B, Bradet F, Chamel R (1993) Diffusion of three ethoxylated octylphenols across isolated plant cuticles. Pestic Sci 38, 201-209

Coupland D, Zabkiewicz JA, Ede FJ (1989) Evaluation of three techniques used to determine surfactant phytotoxicity. Ann Appl Biol 115, 147-156

Crouzet A, Resch F (1993) Embruns marins pollués : origine, formation, action sur la végétation terrestre. Bibliographie Sci Rep Port-cros Natl Park Fr 15, 189-217

Deveze L, Sigoillot JC (1978) Les arbres malades de la mer. Eau Aménagement 19, 13-24

Dowden HGM, Lambert MJ (1979) Environmental factors associated with a disorder affecting tree species on the coast of New South Wales with particular reference to Norfolk Island pines Araucaria heterophylla. Environ Pollut 19, 71-84

Franich RA, Wells LG (1980) Inhibition of $P$ radiata primary needle epicuticular wax biosynthesis by trichloroacetate. J Exp Bot 31, 829-838

Garrec JP, Sigoillot JC (1992) Les arbres malades de la mer. Recherche 23, 940-941

Gellini R, Pantani F, Grossoni F, Bussotti E, Barbolani $E$, Rinallo C (1985) Survey of the deterioration of the coastal vegetation in the park of San Rossore in central Italy. Eur J For Path 13, 296-304

Giovannelli G, Bonasoni P, Loglio G, Ricci C, Tesei U, Cini $R$ (1988) Evidence of anionic surfactant enrichment in marine aerosol. Mar Pollut Bull 19, 274-277

Grieve AM, Pitman MG (1978) Salinity damage to Norfolk Island pines caused by surfactants. III. Evidence for stomatal penetration as the pathway of salt entry to leaves. Aust J Plant Physiol 5, 387-95

Guidi L, Lorenzini G, Soldatini GF (1988) Phytotoxicity of sea-water aerosols on forest plants with special reference to the role of surfactants. Environ Exp Bot 28, 85-94
Hoenig M (1981) L'analyse par spectrométrie d'absorption des polluants métalliques dans les divers compartiments de l'environnement rural. Rev Agric 34, 1525-1534

Jetter R, Riederer M (1994) Epicuticular crystals of nonacosan-10-ol: in-vitro reconstitution and factors influencing crystal habits. Planta 195, 257-270

Kloster G, Klumpp E, Schwuger MJ (1993) Surfactants and complexing agents: new tasks for specimen banking? Sci Total Environ 139/140, 479-490

Loglio G, Innocenti N Degli, Gellini R, Pantani F, Cini R (1989) Detergents as a condition of pollution from coastal marine aerosol. Mar Pollut Bull 20, 115-119

McWilliams EL, Sealy RL (1987) Atmospheric chloride: its implication for foliar uptake and damage. At mosph Environ 21, 2661-2665

Moodie EG, Stewart RS, Bowen SE (1986) The impact of surfactants on Norfolk Island pines along Sydney coastal beaches since 1973. Environ Pollut 41, 153164

Moricca S, Paoletti E, Comparini C (1993) The behaviour of oaks in response to natural and induced exposure to the surfactant ABS. Ann Sci For 50 (suppl 1), 61s-65s

Oosting $\mathrm{HJ}$ (1945) Tolerance to salt spray of plants of coastal dunes. Ecology 26, 85-89

Pitman MG, Dowden HGM, Humphrys R, Lambert MJ, Grieve AM, Scheltema GH (1977) The outfall connection. Aust Nat Hist 19, 73-81

Pyykkö M (1977) Effects of salt spray on growth and development of Pinus sylvestris L. Ann Bot Fenn 14 49-61

Riederer M, Badot PM, Garrec JP, Richard B, Schreiber $L$, Sümmchen $P$, Ühlig M, Wienhaus O (1995) The plant cuticle as an interface between leaves and airborne pollutants. In: EUROSILVA-Contribution to Forest Tree Physiology, Dourdan (France), 7-10 November 1994, INRA, Paris, 76, 101-118

Riederer M, Schreiber L (1995) Waxes-the transport barriers of plant cuticles. In: Waxes: Chemistry, Molecular Biology and Functions (RJ Hamilton, ed). The Oily Press, West Ferry, 131-156

Rosen MJ (1977) Comparative effects of chemical structure and environment on the adsorption of surfactants at the L/A interface and on micellization. In: Solution Chemistry of Surfactants (KL Mittal, ed), Hopewell Junction, New York, USA, 2, 45-55

SAS (1985) SAS User's Guide, version 5. SAS Institute Inc, Cary, NC, USA

Schönherr J, Bukovac MJ (1972) Penetration of stomata by liquids. Plant Physiol 49, 813-819

Schönherr J, Huber R (1977) Plant cuticles are polyelectrolytes with isoelectric points around three. Physiology 59, 145-150

Schönherr J, Riederer M (1988) Desorption of chemicals from plant cuticles: evidence for asymmetry. Arch Environ Contam Toxicol 17, 13-19

Schönherr J, Riederer M (1989) Foliar penetration and accumulation of organic chemicals in plant cuticles. Rev Environ Contam Toxicol 108, 1-70 
Schreiber L. (1994) Comparative investigations of cuticular permeability of conifer needles from healthy and damaged trees. New Phytol 128, 251-261

Schreiber L, Schönherr J (1992) Analysis of foliar uptake of pesticides in Barley leaves: role of epicuticular waxes and compartmentation. Pestic Sci 36, 213-221

Schreiber L, Schönherr J (1992) Uptake of organic chemicals in conifer needles: surface adsorption and permeability of cuticles. Environ Sci Technol26, 153-159

Schreiber L, Schönherr J (1993) Uptake of two chlorinated chemicals in conifer needles: reversibility and compartmental analysis. New Phytol 123, 547-554

Sigoillot JC (1982) Les aérosols marins en Méditerranée. Composition et phytotoxicité. Thèse, université Aix-Marseille, France, $100 \mathrm{p}$
Stevens PJG, Gaskin RE, Hong SO, Zabkiewicz JA (1991) Contributions of stomatal infiltration and cuticular penetration to enhancements of foliar uptake by surfactants. Pestic Sci 33, 371-382

Stock D, Holloway PJ (1993) Possible mechanisms for surfactant-induced foliar uptake of agrochemicals. Pestic Sci 38, 165-177

Thoumelin G (1990) Comportement des tensio-actifs anioniques (LAS) et non-ioniques (APE) dans les effluents urbains, les eaux douces et les eaux marines. Rapport Ifremer, DRO EL-90 09, $113 \mathrm{p}$

Tools J, Kloepper-Sams P, Sijm DTHM (1994) Surfactant bioconcentration: a critical review. Chemosphere 29, 693-717

Wells BW, Shunk IV (1938) Salt spray: an important factor in coastal ecology. Bull Torrey Bot Club 65, 485-493 